\title{
Comparison of breeding values and genetic trends for production traits estimated by a Lactation Model and a Fixed Regression Test-day Model
}

\author{
B.E. Mostert ${ }^{1 \#}$, H.E. Theron ${ }^{1}$, F.H.J. Kanfer ${ }^{2}$ and E. van Marle-Köster ${ }^{3}$ \\ ${ }^{1}$ ARC-LBU, Private Bag X2, Irene 0062, South Africa \\ ${ }^{2}$ Department of Statistics, University of Pretoria, Pretoria 0002, South Africa \\ ${ }^{3}$ Department of Animal and Wildlife Sciences, University of Pretoria, Pretoria 0002, South Africa
}

\begin{abstract}
A comparison of breeding values and genetic trends of production traits from two models is made. One set of breeding values and trends was estimated by the September/October 2003 South African National Genetic Evaluation, using a Lactation Model (LM). The other set was obtained in the 2004 South African National Genetic Evaluation, using a Fixed Regression Test-day Model (TDM). This comparison is made for Ayrshire, Guernsey, Holstein and Jersey cows participating in the South African Dairy Animal Improvement Scheme. Specific differences between the two models were documented, with differences in statistical methodology and inclusion of test-day records of the first three parities in the TDM vs. only first lactation 305-day yields in the LM, as the main differences. Significant reranking of especially cows and unproven sires occurred between the models. Genetic trends of the TDM were not as steep as those from the LM, as the trait that was selected was first lactation yield, while the TDM trends reflect genetic progress over the first three parities.
\end{abstract}

Keywords: Ayrshire, correlations, dairy cattle, Guernsey, Holstein, Jersey, ranking

${ }^{\#}$ Corresponding author. E-mail: Bernice@arc.agric.za

\section{Introduction}

Genetic evaluation of production traits in dairy cattle can be improved by using test-day observations (Test-day Models) instead of aggregated 305-day production records (Lactation Models) (Ptak \& Shaeffer, 1993; Reents et al., 1995a; Jamrozik et al., 1997; Schaeffer et al., 2000; Lidauer et al., 2003). Breeding values, based on production in the first three lactations and estimated with Fixed Regression Multiple Lactation Repeatability Test-day Models, have been released in South Africa during 2004 for Ayrshire, Guernsey, Jersey and Holstein breeds. As in other countries, changing from a Lactation to a Test-Day Model caused significant changes in the ranking of animals. After the Canadian Test-Day Model evolved over a period of seven years, Schaeffer et al. (2000) remarked that efforts to inform the dairy industry about changes in EBV due to the new model, were significantly challenging. This can definitely be confirmed by the authors (B.E. Mostert, unpublished results). The aim of this paper was to document the differences between the two models, to quantify the rank changes in the South African dairy populations and to make recommendations for improvement of the Test-day Model for future reference.

\section{Materials and Methods}

Milk, butterfat and protein breeding values (EBVs) from the September/October 2003 South African National Genetic Evaluation were based on first lactation 305-day production records and estimated using a Lactation Model (LM). These EBVs were compared to milk, butterfat and protein breeding values estimated in the 2004 South African National Genetic Evaluation, based on the first three lactations using test-day records, estimated with a Fixed Regression Multiple Lactation Repeatability Test-day Model (TDM). This was done for Ayrshire, Guernsey, Holstein and Jersey cows participating in the South African Dairy Animal Improvement Scheme (Mostert et al., 2006). A TDM, using only first lactation test-day records, was also run for the Holstein and Guernsey breeds to compare breeding values from first lactation test-day records, with breeding values from first lactation 305-day records (LM), as well as with breeding values from the TDM, including test-days from the first three lactations. Pearson correlations were obtained using SAS (1996) for animals which had breeding values in both evaluations. Bulls were grouped into Proven Sires, 
having daughters in at least 10 herds, and Unproven Sires, having daughters in less than 10 herds. Only measured cows were compared. Genetic trends for milk yield from the TDM and LM were obtained by averaging the breeding values of measured cows per birth year (TDM), or lactation year (LM).

\section{Results and Discussion}

Records of second and later lactations provide more complete information on lifetime performance than using records from first lactations only (Powell \& Norman, 1981). The inclusion of records of the first three lactations in the TDM was therefore a welcomed and long awaited step forward for the dairy industry. It had, however, a significant effect on the ranking of animals when compared to breeding values of the LM, which were based on first lactation records only. This particularly influenced "late bloomers" and their sires, only producing to their full potential in the second and later lactations and now being recognized by the TDM. Also, the inclusion of short lactations (lactations ending before 240 days in milk) in the TDM allows for penalization of sires breeding a high percentage of daughters having short lactations. In the LM, these records were not included. As short lactations are mainly due to selection against low production, certain sires' breeding values were therefore previously overestimated with the LM. A part of ranking differences between the two models is of course due to inclusion of new data in the TDM since the 2003 LM evaluations, for all breeds.

A disadvantage of implementing the TDM, however, is that lactation records have been stored on the Integrated Registration and Genetic Information System (INTERGIS) since 1978, but test-day records only since 1988/89, resulting in the TDM being based on two generations less data, compared to the LM. This has a particular effect on the accuracy of evaluations of dams of currently active cows, as their breeding values are now based solely on progeny and not their own performance. This effect will gradually disappear after a sufficient number of years of test-day records has accumulated. The INTERBULL (International Bull Evaluation Service) Guidelines for National and International Genetic Evaluation Systems in Dairy Cattle with Focus on Production Traits (2001) recommend that genetic evaluation for production traits should be based on at least 15 years of data. For the production evaluations using the TDM, this recommendation is met, but for somatic cell score, where records have been stored on the INTERGIS only since 1996, a few years of data are still lacking to meet this criterion.

The TDM allows for records from cows with unknown parents, while the LM required that at least one parent should be known. Also, records where only milk yield measurements were available were included in the TDM, while milk, butterfat and protein yields should have been known for a cow to be included in the LM.

Genetic grouping in the pedigree is important in achieving accurate evaluations by defining different populations from which animals arise (Pollak \& Quaas, 1983). Unknown parents in the pedigree are replaced by genetic groups, which provide a substitute genetic value for an unknown parent. The genetic value of such a group is determined by all animals, which are connected to this specific group (Handbook NRS, 2004). The INTERBULL Guidelines for National and International Genetic Evaluation Systems in Dairy Cattle with Focus on Production Traits (2001) recommend that genetic groups should have a minimum of 10-20 animals. Some of these groups consisted of less than 10 animals in the LM. It was therefore decided to redefine the genetic groups for all breeds when the TDM was implemented, e.g. for the Jersey breed 37 groups were defined in the pedigree for the TDM vs. 90 groups in the LM. The function of genetic groups is specific for each animal and depends on the number of generations to the base phantom ancestors and on the genetic groups to which those phantom ancestors are assigned (Westell et al., 1988). Thus, changes in genetic group definition caused differences in the breeding values of the two models. Unknown parents were grouped according to country of origin, selection path and birth date. Separate genetic groups were therefore defined for foreign and domestic sires and dams.

The modelling of fixed and random effects for breeding value estimation differed between the LM and TDM, as completely different methodologies and data structures were being used. For the LM the contemporary group was defined as herd $\mathrm{x}$ test year $\mathrm{x}$ status (commercial vs. registered cows), age at calving was included as a fixed effect (six classes) and a sire $\mathrm{x}$ herd interaction was also fitted as a random effect to account for possible preferential treatment. For the TDM the contemporary group was defined as herd $\mathrm{x}$ testdate $\mathrm{x}$ parity $\mathrm{x}$ number of milkings. This is probably the most important advantage of the TDM compared to the LM, as factors specific to each test-day can be accounted for (Jamrozik et al., 1997). Meyer et al. (1989) 
and Rekaya et al. (1995) reported that fitting a herd $\mathrm{x}$ test-date effect reduced the residual variances in comparison to analyses comparing tests in the same herd $\mathrm{x}$ year $\mathrm{x}$ season, while Swalve (1995) found an increase in additive and permanent environmental variance and a decrease in residual variance for herd $\mathrm{x}$ test-date models. Ptak \& Schaeffer (1993) concluded that with the herd x test-date effect, a more precise adjustment for seasons as they affect each test-day, can be made. In the TDM age at calving was included as a fixed effect (14 classes across lactations) to account for the effect of age at calving on yield. The Wilmink curve was modelled on days in milk within lactation (three classes) and season (two classes) to account for the effect of stage of lactation on yield. Calving interval was included as a fixed effect (nine classes) to account for the effect of length of the calving interval on milk yield in the following lactation. Lastly, a permanent environmental effect (random) was fitted across lactations to account for a common effect of the environment associated with all test-day records of a cow. Variance components estimated with these models were considerably lower for the TDM, compared to the LM for all the breeds. It is also important to note that different traits are involved in these evaluations, i.e. production per day, analyzed by the TDM and accumulated 305-day production, analyzed by the LM. The lower heritability estimates of the TDM resulted in a narrower spread for the TDM's estimated breeding values.

Both models were multitrait evaluations, where milk, butterfat and protein yields were analyzed together in order to utilize the genetic correlations between the traits for accurately estimating the breeding values. This is especially important for future evaluations, as, since 2001, the South African Dairy Animal Improvement Scheme allows breeders to only record milk yields with measurement of butterfat and protein yields becoming optional (Dr. J. Van der Westhuizen, 2001: Personal communication, Team Leader : Animal Recording and Improvement, e-mail : japie@arc.agric.za).

As the INTERBULL Guidelines for National and International Genetic Evaluation Systems in Dairy Cattle with Focus on Production Traits (2001) recommend that the base year should change in 2005 to 2000, it was decided to implement this change already in 2004. A second adaptation by the industry following the introduction of breeding values from the TDM, was thereby avoided. Because three lactations were included in the TDM evaluations, the base year had to be redefined from cows tested in 1995, to cows born in 2000. This resulted, therefore, in a drastic change (around seven years) in the base year, with breeding values of the whole population moving down. This is, however, only a scale effect and the ranking of the animals was not influenced. For the Ayrshire and Guernsey breeds, being small populations, this base change was too drastic, resulting in few sires having positive breeding values from the TDM. It was decided then to use cows born in 1995 as their base, a shift of around three years.

In Figures 1-4 genetic trends for milk yield for the Ayrshire, Guernsey, Holstein and Jersey breeds are indicated. Genetic trends are expressed on year of birth for breeding values of the TDM and not test year, as was done with breeding values from the LM. Since 1987 when breeding values were first introduced to the industry using a Sire Model (Loubser et al., 2001), the trait that has been selected for, was first lactation yield. Trends from the TDM are therefore not as steep as those from the LM, as they indicate genetic progress over the first three lactations, while trends from the LM indicate progress in first lactation yield, which was the selected trait. Furthermore, inclusion of short lactations in the TDM will also have a declining effect on the trends. The difference in the base year can also be observed from the graphs: cows born in 2000 (TDM) versus cows tested in 1995 (LM) for the Holstein and Jersey breeds and cows born in 1995 (TDM) versus cows tested in 1995 (LM) for the Ayrshire and Guernsey breeds, causing a time lag between the trends.

Trends from the LM show clearly that significant progress was achieved in first lactation milk yield since 1978 in all breeds. Linear regressions quantified this progress as $41.9 \mathrm{~kg} / \mathrm{year}\left(\mathrm{R}^{2}=97 \%\right)$ for Ayrshires, $29.0 \mathrm{~kg} /$ year for Guernseys $\left(\mathrm{R}^{2}=99 \%\right), 53.6 \mathrm{~kg} /$ year $\left(\mathrm{R}^{2}=98 \%\right)$ for Holsteins and $29.5 \mathrm{~kg} / \mathrm{year}$ for Jerseys $\left(\mathrm{R}^{2}=98 \%\right)$. Progress in milk yield over the first three lactations (TDM-trends), showed, however, different pictures for the breeds. For Ayrshires almost the same progress was achieved in yield over the first three lactations compared to yield in the first lactation, with a slightly higher regression coefficient of $50.1 \mathrm{~kg} /$ year $\left(\mathrm{R}^{2}=94 \%\right)$. Initially progress in the first three lactations of the Guernsey breed was almost parallel to progress in the first lactation, but since 1992 the trend did not change significantly. Progress in milk yield of the first three lactations was $13.8 \mathrm{~kg} /$ year $\left(\mathrm{R}^{2}=82 \%\right)$ for the Guernsey breed. Although the regression coefficient for the TDM-trend of the Holsteins was higher $\left(58.1 \mathrm{~kg} /\right.$ year; $\left.\mathrm{R}^{2}=90 \%\right)$ compared to that of the LM-trend, progress was achieved in the earlier years up to 1996, after which it stabilized. 
74

South African Journal of Animal Science 2006, 36 (2)

(C) South African Society for Animal Science

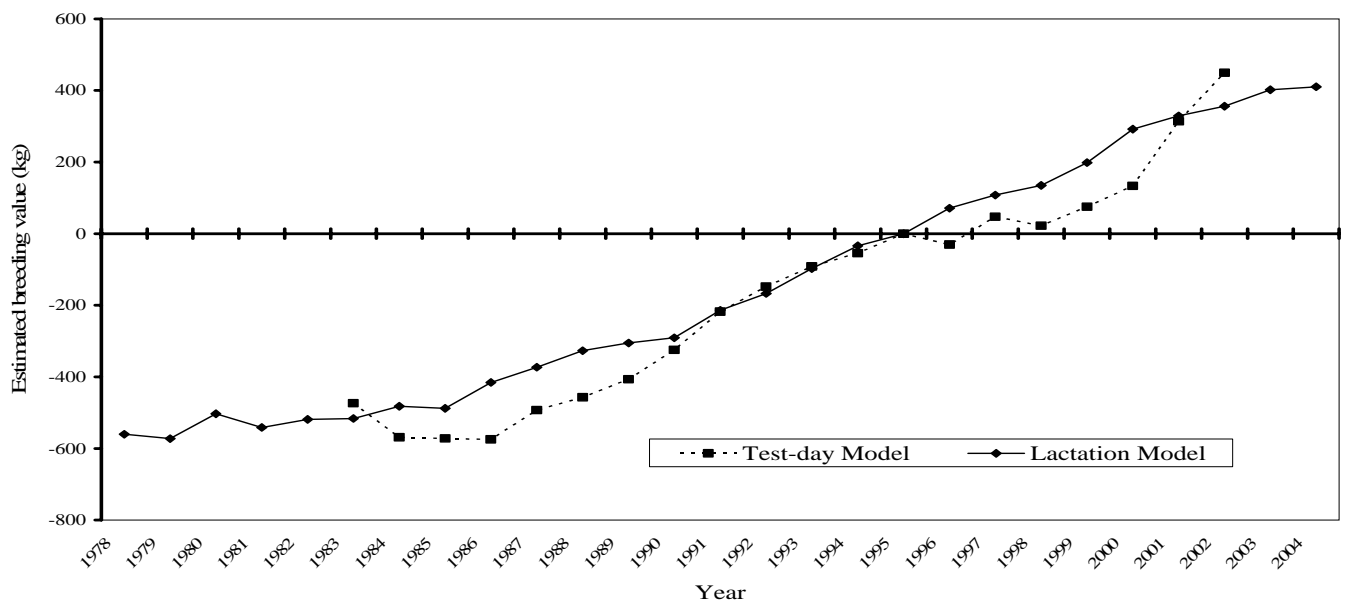

Figure 1 Genetic trends for milk yield of Ayrshire cattle

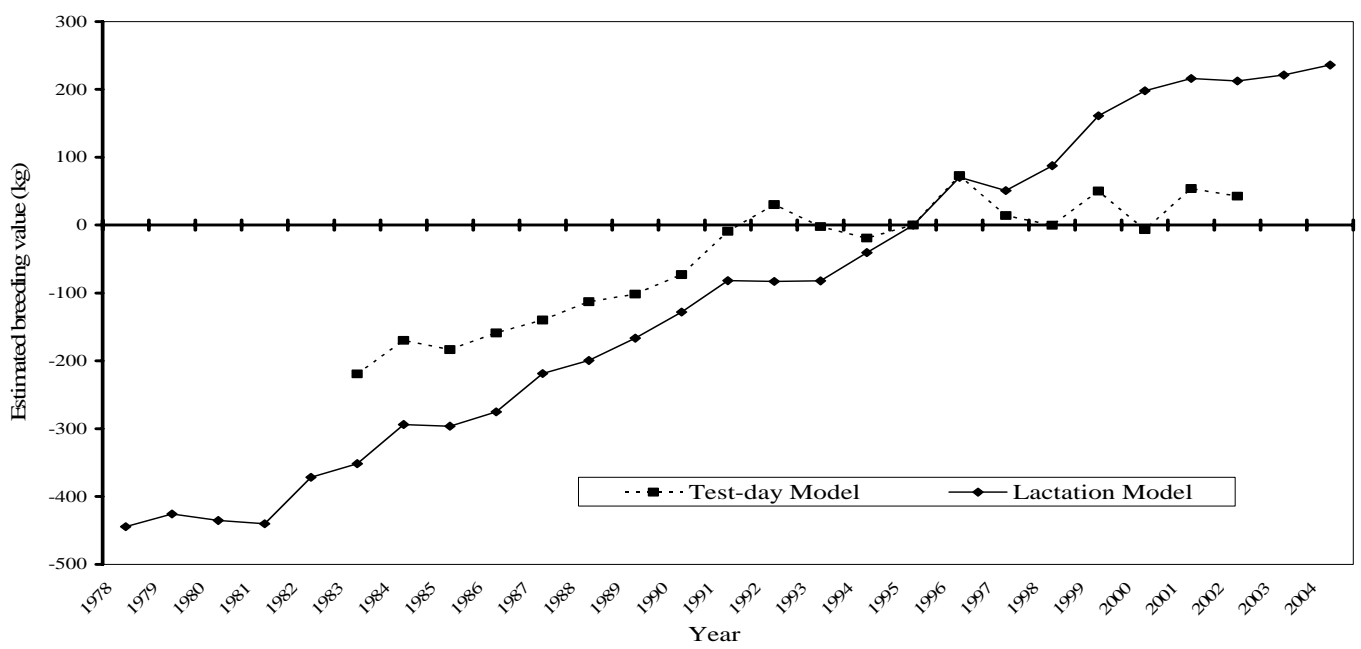

Figure 2 Genetic trends for milk yield of Guernsey cattle

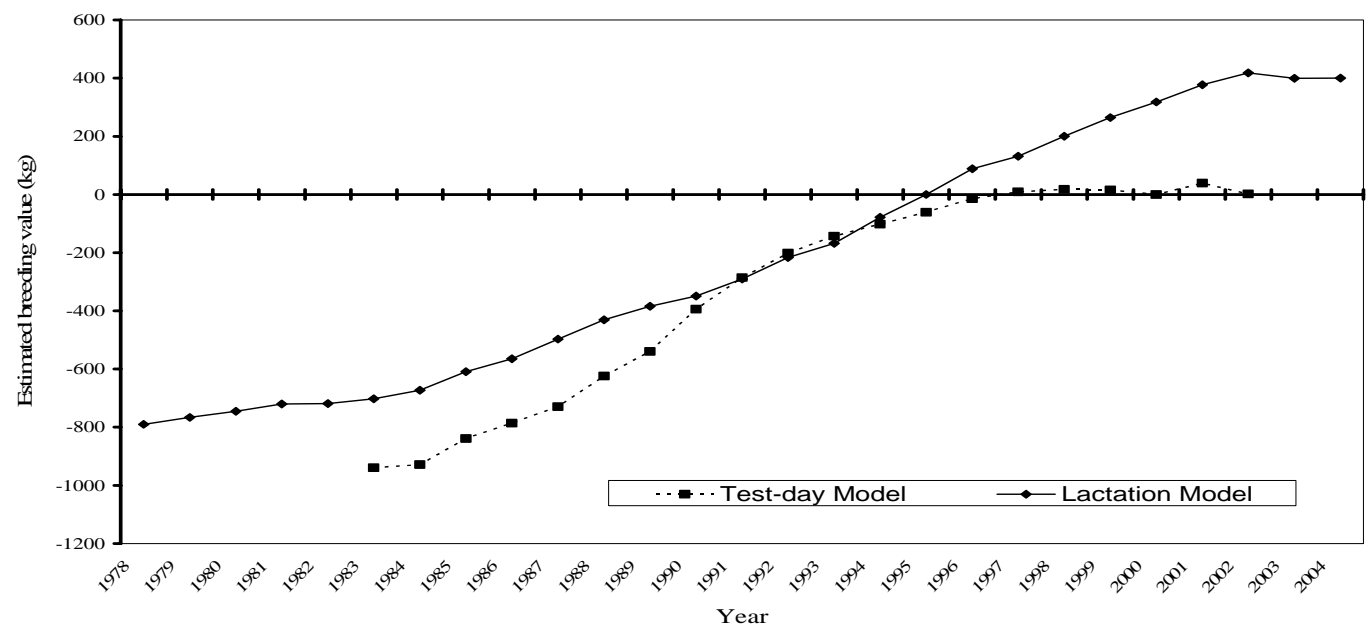

Figure 3 Genetic trend for milk yield of Holstein cattle

The South African Journal of Animal Science is available online at http://www.sasas.co.za/sajas.asp 


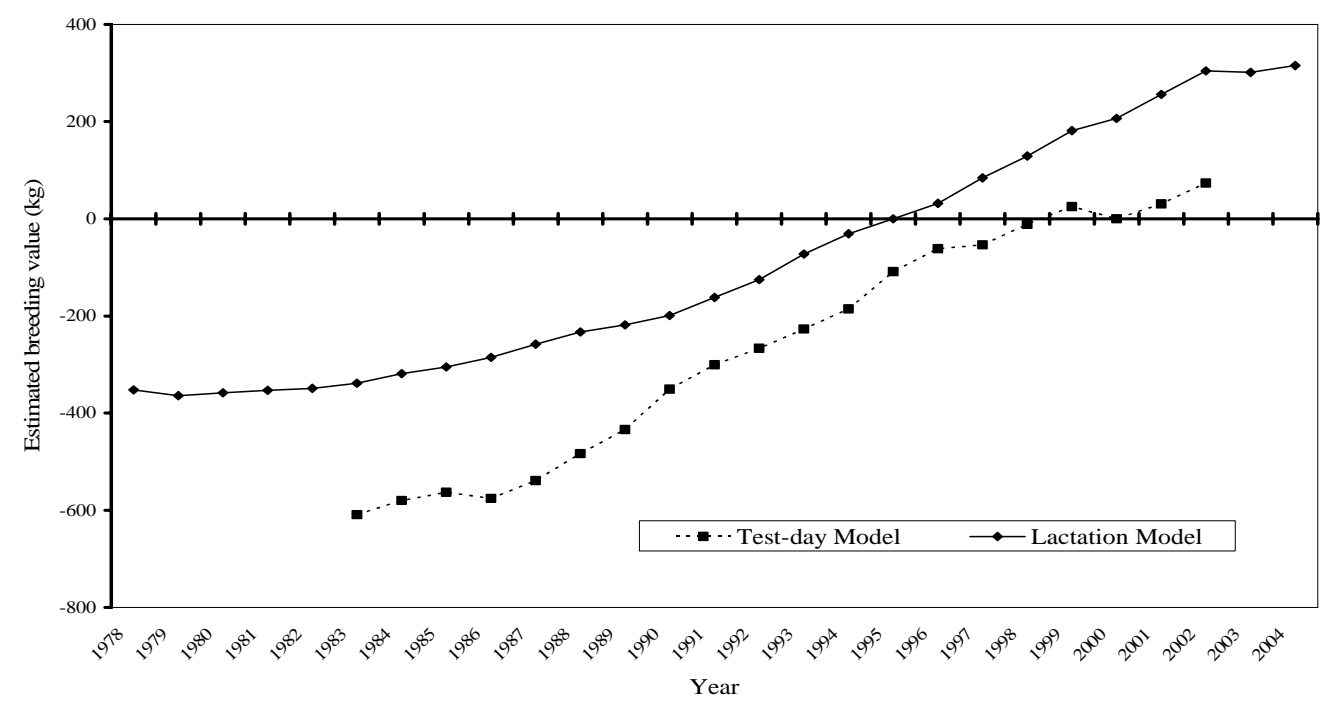

Figure 4 Genetic trends for milk yield of Jersey cattle

The Jersey breed, however, also showed comparable progress in the first three lactations with that of the LM-trend, with a regression coefficient of $40.2 \mathrm{~kg} /$ year $\left(\mathrm{R}^{2}=98 \%\right)$. In fact, the difference between the two trends for the Jersey breed can be attributed largely to the difference in the base year adaptation. It is, however, important to note that all the data for the last year of the trends were not yet included in the evaluations and that the different heritabilities involved in the TDM and LM also influence the rate of genetic progress. Reents et al. (1998) showed that the genetic trend is significantly higher from test-day models in comparison to lactation models. The same number of lactations was, however, involved in their study.

Table 1 Pearson Correlations $(\mathrm{P}<0.0001)$ between breeding values from three models for proven, unproven and measured cows of the Holstein and Guernsey breeds

\begin{tabular}{|c|c|c|c|c|c|c|}
\hline & \multicolumn{3}{|c|}{ Holstein } & \multicolumn{3}{|c|}{ Guernsey } \\
\hline & Milk & Butterfat & Protein & Milk & Butterfat & Protein \\
\hline \multicolumn{7}{|c|}{ Proven Sires } \\
\hline TDM vs. LM & 0.91 & 0.88 & 0.89 & 0.86 & 0.83 & 0.83 \\
\hline $1^{\text {st }}$ TDM vs. LM & 0.94 & 0.91 & 0.92 & 0.89 & 0.87 & 0.87 \\
\hline $1^{\text {st }}$ TDM vs. TDM & 0.96 & 0.95 & 0.96 & 0.90 & 0.91 & 0.89 \\
\hline \multicolumn{7}{|c|}{ Unproven Sires } \\
\hline TDM vs. LM & 0.89 & 0.87 & 0.87 & 0.63 & 0.61 & 0.62 \\
\hline $1^{\text {st }} \mathrm{TDM}$ vs. LM & 0.91 & 0.88 & 0.89 & 0.82 & 0.77 & 0.79 \\
\hline $1^{\text {st }}$ TDM vs. TDM & 0.95 & 0.95 & 0.94 & 0.88 & 0.85 & 0.86 \\
\hline \multicolumn{7}{|c|}{ Measured Cows } \\
\hline TDM vs. LM & 0.88 & 0.84 & 0.86 & 0.72 & 0.67 & 0.69 \\
\hline $1^{\text {st }} \mathrm{TDM} v s . \mathrm{LM}$ & 0.92 & 0.87 & 0.91 & 0.83 & 0.81 & 0.80 \\
\hline $1^{\text {st }}$ TDM vs. TDM & 0.93 & 0.94 & 0.92 & 0.85 & 0.82 & 0.85 \\
\hline
\end{tabular}

$1^{\text {st }}$ TDM - Test-day Model including only test-day records of the first lactation TDM - Test-day Model including test-day records of the first three lactations LM - Lactation Model including 305-day yields of first lactations 
In Table 1 Pearson Correlations between breeding values from the Test-day Model and Lactation Models are indicated for proven sires, unproven sires and measured cows for the Holstein and Guernsey breeds, and in Table 2 for the Ayrshire and Jersey breeds. Ranks between breeding values of the TDM and LM (Table 1 and 2) are in the high eighties and low nineties for proven sires of all breeds, with milk yield ranking the highest of the yield traits. For the small breeds, rankings were lowest for unproven sires for all traits compared to those of proven sires and cows. For the Holstein breed unproven sires ranked lowest for all traits and for the Jersey breed unproven sires and cows ranked the same, except for butterfat yield where the unproven sires ranked lower than the cows. These rankings were within the ranges reported in the literature. Reents et al. (1995b) reported correlations between breeding values for protein yield from a fixed regression test-day model and breeding values from a lactation average model, including test-days from the first three lactations. Correlation of $84 \%$ for sires having more than 100 daughters and $73-81 \%$ for sires having less than 100 daughters were published. Correlations between cow breeding values were in the range similar to correlations for bulls with a low number of daughters (i.e. 78\%). In 1998 Reents et al. concluded that ranking of bull breeding values from test-day models compared to a lactation model changed substantially and published correlations in the range of $94 \%$ and for cows in the range of $87 \%$.

According to Schaeffer et al. (2000) rankings for Canadian bulls ranged from $88 \%$ for the Brown Swiss (one of the breeds with the fewest number of animals) to $97 \%$ for the Holstein (breed with greatest number of animals) when comparing breeding values from a LM with that of a random regression test-day model. Lidauer et al. (2003) published high correlations between active bulls' breeding values (0.99 for milk, 0.98 for butterfat and protein) from a LM and random regression test-day model. However, the animals and data of their study were carefully selected to be the same across different models in contrast to the other mentioned publications. For young cows the corresponding correlations were about $88 \%$, which led to significant re-ranking of cows. Other rankings reported in the literature were all in the range of $87-97 \%$ (Swalve, 1995; Reents \& Dopp, 1996; Jamrozik et al., 1997; Lidauer et al., 2000; Emmerling et al., 2002).

Table 2 Pearson Correlations $(\mathrm{P}<0.0001)$ between breeding values of two models for proven sires, unproven sires and measured cows of the Ayrshire and Jersey breeds

\begin{tabular}{|c|c|c|c|c|c|c|}
\hline & \multicolumn{3}{|c|}{ Ayrshire } & \multicolumn{3}{|c|}{ Jersey } \\
\hline & Milk & Butterfat & Protein & Milk & Butterfat & Protein \\
\hline \multicolumn{7}{|c|}{ Proven Sires } \\
\hline TDM vs. LM & 0.89 & 0.87 & 0.86 & 0.92 & 0.90 & 0.89 \\
\hline \multicolumn{7}{|c|}{ Unproven Sires } \\
\hline TDM vs. LM & 0.80 & 0.81 & 0.80 & 0.89 & 0.87 & 0.88 \\
\hline \multicolumn{7}{|c|}{ Measured Cows } \\
\hline TDM vs. LM & 0.86 & 0.86 & 0.85 & 0.89 & 0.88 & 0.88 \\
\hline
\end{tabular}

The impact of using the TDM compared to the LM (Table 1) can be seen from the correlation estimates of breeding values from the TDM, including only first lactation records and breeding values from the LM. Differences in methodology therefore cause proven sires of the Holstein breed to re-rank with 6-9\% and proven Guernsey sires with 11-13\%, depending on the trait. Inclusion of second and third parity records in the TDM cause rankings for proven sires to be 3\% lower for all traits of the Holstein breed (differences between rankings of TDM and LM with $1^{\text {st }} \mathrm{TDM}$ and LM). For the Guernsey breed the rankings of the proven sires were 3\% lower for milk yield, and $4 \%$ for butterfat and protein yields. The same trends can be observed for the unproven sires and cows of both breeds. Reents et al. (1995b) reported correlations of 3.67.3\% lower, depending on the number of daughters involved. This was obtained by comparing correlations 
between protein breeding values from a fixed regression test-day model and breeding values from a lactation average model. It included test-days from the first three lactations, with correlations from a fixed regression test-day model, including test-day records from the first three lactations and breeding values from a lactation average model, including test-days from only the first lactation.

When using the same methodology, the effect of inclusion of second and third lactation records (Table 1) on rankings can be seen from the correlation estimates between breeding values based on a TDM including only first lactation records and a TDM including records from the first three lactations. This caused re-rankings of $4-5 \%$ in proven Holstein sires and 9-11\% in proven Guernsey sires, depending on the trait. Again the impact of using different methodologies can be quantified when comparing these correlation estimates with those obtained between breeding values for a TDM including only first lactation records and breeding values from the LM. This causes the ranks to decrease by $2-4 \%$ for proven sires of the Holstein breed and 1-4\% for proven sires of the Guernsey breed, depending on the trait. The same trends can be observed for the unproven sires and cows of both breeds.

Differences in methodology therefore had a slightly larger effect on the rankings of animals than inclusion of second and third lactation records.

\section{Conclusions}

Implementation of the Fixed Regression Multiple Lactation Repeatability Test-day Model to estimate breeding values for production traits of dairy breeds caused significant re-rankings of especially cows and unproven sires. Genetic trends now reflect genetic progress in production over the first three lactations and not only first lactation progress, as with the previously used LM. Some refining of the TDM should, however, still be done. The possible inclusion of a fixed calving year in the model should be investigated for improving the strange ranking of some of the older sires. Furthermore, tests in the beginning and at the end of lactation have higher phenotypic variance than tests in the middle of lactation and first lactations have a lower mean and variance compared to second and third lactations. Adjusting for heterogeneous variance due to days in milk and parity are therefore worth investigating. This will especially influence breeding values of first lactation cows, as well as those of young sires having only first lactation daughters and all these daughters are still in progress early in the lactation.

\section{References}

Emmerling, R., Lidauer, M. \& Mäntysaari, E.A., 2002. Multiple lactation random regression test-day model for Simmental and Brown Swiss in Germany and Austria. Interbull Meeting, Interlaken Switzerland, 26-27 May, 111-117.

Handbook NRS, 2004. Statistical Indicators. E-7. Breeding value estimation of milk production traits with test-day model. CR Delta.

INTERBULL Guidelines for National and International Genetic Evaluation Systems in Dairy Cattle with Focus on Production Traits, 2001. Bulletin No. 28. Department of Animals Breeding and Genetics, Uppsala, Sweden.

Jamzorik, J., Schaeffer. L.R. \& Dekkers, J.C.M., 1997. Genetic evaluation of dairy cattle using test-day yield and random regression model. J. Dairy Sci. 80, 2550-2556.

Lidauer, M., Mäntysaari, E.A. \& Strandén, I., 2003. Comparison of test-day models for genetic evaluation of production traits in dairy cattle. Livest. Prod. Sci. 79, 73-86.

Loubser, L.F.B, Banga, C.B., Scholtz, M.M. \& Hallowell, G.J., 2001. The use of breeding values in the South African Dairy Industry.Dairy Herd Improvement in South Africa. 25.

Meyer, K., Grase, H.-U. \& Hammond, K., 1989. Estimation of genetic parameters for first lactation test-day production of Australian Black and White cows. Livest. Prod. Sci. 21, 177-199.

Mostert, B.E., Theron, H.E., Kanfer, F.H.J. \& Van Marle-Köster, E., 2006. Fixed regression test-day models for South African dairy cattle for participation in international evaluations. S. Afr. J. Anim. Sci. 36, 5870 .

Pollak, E.J. \& Quaas, R.L., 1983. Definition of group effects in sire evaluation models. J. Dairy Sci. 66, 1503-1509.

Powel, R.L. \& Norman, H.D., 1981. Different lactations for estimating genetic merit of dairy cows. J. Dairy Sci. 64, 321-330. 
Ptak, E., Schaeffer, L.R., 1993. Use of test-day yields for genetic evaluation of dairy sires and cows. Livest. Prod. Sci. 34, 23-34.

Reents, R. \& Dopp, L., 1996. Genetic evaluation for dairy production traits with a test-day model for multiple lactations. Interbull Meeting, Veldhoven, The Netherlands, 23-24 June. pp. 113-117.

Reents, R., Dekkers, J.C.M. \& Schaeffer, L.R., 1995a. Genetic evaluation for somatic cell score with a testday model for multiple lactations. J. Dairy Sci. 78, 2858-2870.

Reents, R., Dekkers, J.C.M. \& Schaeffer, L.R., 1995b. Genetic evaluation with a multiple lactation test-day model for SCS and production traits. Proc. 1995 Interbull Meeting, Prague, Czech Republic, September 7-8, 1-6. Proc. 1995 Interbull Meeting, Prague, Czech Republic, September 7-8, 1-8.

Reents, R., Dopp, L., Schmutz, M. \& Reinhardt, F., 1998. Impact of application of a test-day model to dairy production traits on genetic evaluations of cows. Interbull Meeting, Rotorua, New Zealand, January 18-19. pp. 49-54.

Rekaya, R., Béjar, F., Carabano, M.J. \& Alenda, R., 1995. Genetic parameters for test-day measurements in Spanish Holstein-Friesian.

SAS, 1996. Statistical Analysis Systems user's guide : Release 6.12. SAS Institute Inc., Cary, North Carolina, USA.

Schaeffer, L.R., Jamrozik, J., Kistemaker, G.J. \& Van Doornmaal, B.J., 2000. Experience with a test-day model. J. Dairy Sci. 83, 1135-1144.

Swalve, H.H., 1995. The effect of test-day models on the estimation of genetic parameters and breeding values for dairy yield traits. J. Dairy Sci. 78, 929-938.

Westell, R.A., Quaas, R.L. \& Van Vleck, L.D., 1988. Genetic groups in an animal model. J. Dairy Sci. 71, 1310-1318. 